\title{
DIAKONIA EN KOINONIA
}

Prof. J. H. van Wyk

Wanneer ons wil besin oor die plek en taak van die diaken moet ons dit doen vanuit die gesigspunte van die kerk en Koninkryk van God. Ons siening van die Koninkryk bepaal ons siening van die kerk en ons kerkbegrip bepaal ons kyk op die diakonaat. Daarom het ek dit goed gedink om enkele opmerkinge te makk oor die wese en taak van die kerk, oor die Koninkryk, oor die diakonaat en ten slotte oor die gedagte van gemeenskap. Interessantheidshalwe maak ek gebruik van die Griekse woorde in hierdie verband.

\section{EKKLESIA:}

Die diakonaat moet vanuit die kerk benader word het ons gesê. Die diakens vorm immers 'n deel van die kerk, doen hulle werk in en vir die kerk - en natuurlik ook in en vir die Koninkryk, maar daaroor later.

My bedoeling is nie om hier 'n breedvoerige uiteensetting oor die kerk te gee nie. Ek verwys veral na een gedeelte, weliswaar een van die volledigste gedeeltes, waar ons 'n uitstekende definisie van die kerk aantref naamlik 1 Petrus $2: 9-10$. Hier word veral op twee aspekte van die kerk gewys nl. op die wese van die kerk en op sy roeping, op wat die kerk IS en wat die kerk moet DOEN.

Die WESE van die kerk word met 'n aantal pragwoorde beskryf. Ons let kortliks op elkeen daarvan.

Die kerk is "die uitverkore volk (geslag)" sê Petrus. Die kerk rus dus nie op menslike prestasies en eiegeregtigheid nie maar in Gods uitverkiesende liefde. Hierdie gedagte vorm dan ook die diepste agtergrond vir 'n lewe van dankbaarheid en offer by die gelowige kind van God.

Verder is die kerk "'n koninklike priesterdom". Dit is nogal 'n seldsame kombinasie, veral as ons dink aan die geskeie bestaan van koning en priester in die Ou Testament. Nóú, na die koms van Jesus Christus en noudat 'n nuwe gemeenskap ontstaan het, verval hierdie skeiding en word gepraat van koninklike priesters (of ook "'n heilige priesterdom", 2:4). Daar is dus nou nie meer 'n aparte klomp priesters in die kerk nie, soos in die Rooms-Katolieke Kerk, maar élke gelowige is nou 'n priester. Die Reformasie het hier tereg gespreek van die algemene priesterskap van alle gelowiges. Hierdie gedagte is ook vir die diakonaat belangrik. Die priesterskap en priesterlike diens word nie vernietig nie maar verbreed tot oor die hele gemeente. En van nou af moet die priesterlike diens koninklik uitgevoer word, wat ook niks anders beteken nie as om in die gestalte van 'n dienskneg te dien (Mark $10: 42-44$ ).

Verder word die kerk beskryf as 'n "heilige nasie". Hierdeur word baie sterk klem gelê op die eenheid van die kerk. Die kerk van God bestaan nou nie net meer uit een nasie nl. Israel nie, maar word geroep uit alle volke, tale en nasies. Die kerk word nou gebou uit Israel én die heidennasies en vorm sodoende 'n nuwe en ook unieke eenheid. Hierdie gedagte van die eenheid van die kerk is ook vir die funksionering van die diakonaat van groot betekenis.

Nog 'n omskrywing van die kerk is "die eiendomsvolk van God". In vers 10 word daarvan gepraat dat hierdie verspreidwonendes (1:1) geen volk was nie maar nou die "volk van God" is. Hiermee 
is een van die diepste omskrywinge van die kerk gegee, 'n klaarblyklike toespeling op die Ou Testament en 'n omskrywing wat oorwegend in die Nuwe Testament vir die kerk aangetref word. Daar is ander mooi name vir die kerk, soos bv. liggaam van Christus en ook bouwerk van die Gees, maar die omvattendste en diepsinnigste beskrywing is wel dit dat die kerk genoem word "volk van God". Dit gee uitdrukking aan die unieke karakter van die kerk.

Vir ons doel is hierdie enkele gegewens i.v.m. die kerk voldoende. Ek gaan vervolgens aandag gee aan die roeping van die kerk en doen dit onder die kopstuk Basileia (Koninkryk).

\section{BASILEIA:}

Indien ons goed opgelet het na verse 9 en 10 sou ons dadelik gesien het dat daar 'n besonder noue verband gelê word tussen die wese van die kerk en die roeping van die kerk. Hierdie twee aspekte is inderdaad ook onlosmaaklik aan mekaar verbonde.

Die kerk word geroep om die "verlossingsdade" (deugde) van God te verkondig.

Dit is die eerste taak van die kerk: Hierdie priestervolk van God moet ook profete wees.

Hulle moet die deugde van Gód verkondig. Let goed op hierdie woorde. Hulle word nie geroep om hulle eie deugde, die deugde van die kérk te verkondig nie, ook nie deugde van een of ander groot kerklike figuur nie, nee, dit gaan oor die deugde van die lewende en barmhartige God.

Wat sou hierdie deugde van God dan wees? Gaan dit oor sy skeppingswerk, sy werk van verlossing (Paasfees) en werk van vernuwing (Pinkster)? Op 'n ander plek in die Bybel lees ons ook van mense wat begin praat het oor "die groot dade van God" en wel tydens die uitstorting van die Heilige Gees (Hand. 2:11). En stel ons dan ondersoek in na hierdie groot dade van God waaroor die mens begin praat het, dan blyk dit (uit Petrus se Pinksterpreek) niks anders te wees nie as God se groot dade in Jesus Christus, as die kruisiging en opstanding van Christus (Hand $2: 22-24,36,38$ ). Dit gaan dus veral oor die "verlossingsdade" van die barmhartige God, dit gaan oor die genade wat ons in Christus ontvang het. Dit gaan oor die verlossing deur Christus en die oorwinning van Christus. Dit gaan oor Christus as ons hoogste Profeet, ons enigste Hoëpriester en ons ewige Koning. Dit gaan oor Christus aan wie alle mag in hemel en op aarde gegee is en wie se heerskappy oral op aarde moet sigbaar word. Dit gaan oor Christus as Hoof van die kerk én die kosmos. Dit gaan oor Christus wie se Koninkryk gekom het en eenmaal volledig sal kom.

Ons moet egter hierdie verkondiging van die kerk nie eensydig sien nie. Die kerk het nie net 'n binnekerklike maar ook 'n buitekerklike roeping. Hierdie deugde van God moet dus verkondig word sowel tydens 'n erediens as op die sendingveld en veral ook in die volle lewe. Ook in die wêreld moet die evangelie van die Koninkryk uitgedra word. Alhoewel die kerk dus enersyds van die wêreld afgesonder word, word dit andersyds ook in die wêreld ingestuur om die sout vir die aarde en die lig vir die wêreld te wees. Ook hierdie aspek is van groot belang vir die diakonaat.

Die apostel Petrus wys egter ook op 'n tweede aspek van die taak van die kerk nl. dat die kerk ook "geestelike offers" moet 
bring ( $2: 5)$. Dit gaan dus in die kerk nie net oor woorde nie maar ook oor dade.

Hierdie woord- en daadkarakter van die kerk vind ons telkens in die Nuwe Testament. By die ontstaan van die Nuwe Testamentiese kerk, wanneer Jesus sy twaalf dissipels roep en hulle uitstuur, vind ons reeds hierdie woord- en daadsending. Die Twaalf moet enersyds die Koninkryk gaan verkondig maar ook andersyds dade van gesondmaking en reiniging, duiweluitdrywing en dodeopwekking verrig (Matt. $10: 7-8$ ). Hierdie woord- en daadaspek van die kerk is ook vir die diakonaat van groot belang.

Die vraag is nou waarin hierdie "geestelike offers", waarvan die apostel Petrus skrywe, eintlik bestaan. Volgens Hebreërs kan dit onmoontlik op 'n soenoffer dui; dit het Jesus Christus tog eens vir altyd gebring. Tog is daar nog sprake van ander offers soos bv. danken lofoffers. So word daar ook van hierdie offers melding gemaak in Hebreërs 13: 15-16: "Laat ons dan onophoudelik deur Jesus aan God 'n offer van lof bring, dié lof wat aan Hom gebring word deur die lippe wat sy Naam bely. Moenie nalaat om goed te doen en mededeelsaam te wees nie, want dit is die offers wat vir God aanneemlik is." Hier word weldadigheid en mededeelsaamheid dus genoem as spesifieke offers wat die Christelike gemeente moet bring. Om die hele gemeente hiervoor toe te rus word aan die diakens ' $n$ besondere taak gegee, soos ons nog later sal sien.

Die kerk van God staan binne 'n groot raamwerk nl. die Koninkryk van God. Die kerk is nie daar bloot ter wille van die kerk nie. Die kerk is daar ter wille van die saak van God op aarde, ter wille van die genadige heerskappy van Christus oor alle dinge. Al sy doen en late moet die stempel dra van die Koninkryk. Die kerk moet verkondig dat die Koninkryk gekom het met die koms van Jesus Christus, dat God in Hom die sonde en die dood en die demone oorwin het en dat Hy iets nuuts in die wêreld begin het. Die kerk moet verkondig dat met die koms van die Gees van God 'n nuwe wêreld begin groei uit die ou wêreld. En die kerk moet hierdie verkondiging opvolg deur die doen van goeie dade na binne en na buite. Die heil van God moet immers wêreldwyd sigbaar word.

Die kerk moet hierin die voorbeeld volg van die Messias Jesus, wat nie gekom het om gedien te word nie maar om te dien (Mark $10: 45$ ), wat Homself verneder het en die gestalte van 'n slaaf aangeneem het ter wille van die redding van sondige mense (Filip $2: 6$ ). Die diakonat is ' $n$ diens in en vir die kerk. Maar dit is veral ook 'n diens in en vir die Koninkryk van God.

Ons kom vervolgens by 'n derde aspek $\mathrm{nl}$.

\section{DIAKONIA:}

Ek gaan glad nie breedvoerig handel oor die amp/diens van die diaken nie. Daaroor is in die loop van jare baie besin en ek kan in hierdie verband verwys na die boek Die prys van wat verkoop is. Die diaken vanaf 1935 tot 1975 in Suid-Afrika.' Onlangs is ook weer deur verskillende skrywers indringend oor hierdie onderwerp besin. ${ }^{2}$

Die amp van die diaken, wat selfs al genoem is "die mees twyfelagtige amp in die kerk", 3 lewer probleme omdat die Skrifgegewens daaromtrent taamlik gering is. Gewoonlik word aangeneem dat ons in 1 Tim. 3 en Filip $1: 1$ duidelike uitsprake i.v.m. die diakonaat het terwyl in Rom. $12: 8$ en 1 Kor. $12: 28$ op indirekte wyse daaroor 
gehandel word. Dát daar 'n diakonale amp of diens is, is egter sonder meer duidelik. Die diskussie gaan veral oor wát die amp alles inhou en wat die wese van die diakonale amp dan is.

In hierdie verband het die "instelling" van die diakenamp volgens Hand. 6 sterk ter sprake gekom en ook onder skerp kritiek. Verskillende skrywers het, myns insiens tereg, aangetoon dat Hand. 6 'n te skrale basis vorm om daarop 'n diakonale amp te bou soos ons dit vandag ken. In Hand. 6 gaan dit trouens nie net en ook nie soseer oor versorging nie maar oor die gemeenskapslewe wat in die gemeente van Jerusalem bedreig is. En om hierdie probleem op te los word dan die sewe tafelbediendes verkies. Hulle moes die gemeente inspireer om uit te groei tot 'n dienende liefdesgemeenskap. Die kerk is trouens 'n weergalose liefdesgemeenskap én hy moet dit ook al meer en meer wórd.

Die diakonale amp mag dus nooit verskraal word om alleen armversorging in te sluit nie, nee, die diakonale taak is gerig op die hele gemeente en op die ganse Koninkryk: die hele gemeente moet opgevoed, voorgelig en geaktiveer word tot 'n magtige diensorganisasie van Jesus Christus vir die saak van die Koninkryk van God.

Per slot van rekening sal Christus nie eenmaal vir die diakonie nie maar vir die hele gemeente, vir almal saam en elkeen afsonderlik, vra of hy barmhartigheid aan die nooddruftige bewys het (Matt. $25: 41-45$ ).

Ten einde hierdie saak konkreet toe te lig verwys ek graag na 'n paar voorbeelde: ${ }^{4}$

- besoeke en hulp aan weduwees en wese, by sterfgevalle en geboortes;

- besoeke en hulp aan siekes, eensames, noodlydendes en alkoholiste;

- hulp as baba-oppassers, weeksdae en Sondae;

- besoeke en hulp aan immigrante;

- besoeke en hulp aan nuwe lidmate;

- besoeke en hulp aan militêre dienspligtiges en hul familie;

- besondere hulp aan jong lidmate, bv. studente;

- hulp t.o.v. woningnood en verblyfreëlings;

- bystand aan werkloses, vreemdelinge en vlugtelinge;

- besoeke aan gevangenes, kranksinniges, blindes, dowes, stommes

- hulp aan diakonale en ander rehabilitasie-inrigtings;

- reël van vervoer van oues en siekes na en van eredienste of hospitale;

- hulp aan lidmate wat verhuis;

- hulp in tye van groot rampe (vloed, brand, orkaan, aardbewing, oorlog);

- oprigting van inrigtings vir drank- en ander verslaafdes;

- aandag gee aan loonstrukture van laag besoldigdes;

- aandag aan noodsituasies van wit en swart trekarbeiders;

- opskerping van rykes t.o.v. 'n milde gawe.

So moet die diakens die gemeente stimuleer, organiseer en koördineer om 'n dienende liefdesgemeenskap te wees wat na binne warmte skenk en na buite sy lig laat skyn in die strate van die wêreld.

Maar kom ons onderstreep veral die gedagte van gemeenskap/ koinonia. 


\section{KOINONIA:}

Die diakonale taak het ten minste vier aspekte en ek noem dit: binnekerklik, tussenkerklik, interkerklik en buitekerklik. Dit is noodsaaklik om hieroor enkele opmerkings te maak. Die koinonia-motief funksioneer in al vier gevalle, die sterkste by die eerste twee.

Allereers die binnekerklike taak.

Ons het reeds in hierdie verband na Hand. 6 verwys waar ons miskien nie te doen het met die instelling van die diakenamp nie maar seker met die vroegste wortels daarvan. As ons Hand. 6 ook saamlees met Hand $2: 42$, waar die vier kenmerke van die vroegste erediens vermeld word ( $\mathrm{nl}$. prediking, gemeenskap, nagmaal en gebed), dan val daar ook meer lig op die taak van die eerste sewe "diakens" en hulle opvolgers. Die twaalf apostels sou nl. voortaan konsentreer op die Woordbediening en gebed en die sewe diakens op die bediening van die koinonia en die nagmaal.

Die diakens het 'n onmiskenbare taak in die plaaslike gemeente. Hierdie taak word toegespits op die aanwakker van die koinonia-motief. Die gemeente moet in gemeenskap eet. Hulle moet 'n verlossingsen versoenings- en liefdesgemeenskap wees. Daar moet nie liefdeloosheid, dwarstrekkery, ontevredenheid, eensaamheid en moedeloosheid in 'n gemeente heers nie. En natuurlik moet daar ook nie armoede, honger, naaktheid en dakloosheid voorkom nie. Al sal ons die armes altyd by ons hê (Deut. $15: 11$, Matt $26: 11$ ), is dit vir ons geen alibi dat hulle altyd daar moét wees nie, nee, ons hulpverlening moet sodanig wees dat daar "géén arme moét wees nie" ((Deut. 15:4). Lees ons dan nie van die eerste gemeente in Jerusalem dat "niemand onder hulle behoeftig was nie"? (Hand $4: 34$ ).

Waar daar koinonia is, waar daar gemeenskap in die geloof is, daar kom ook gemeenskap in die onderlinge saamleef en saambestaan.

Tweedens het die diakens ook 'n tussenkerklike taak.

Elke gemeente is wel selfstandig maar nooit sonder verband met ander gemeentes nie. Ons het gesien dat die apostel Petrus pertinent gehandel het oor die eenheid van die kerk en ons vind hierdie gedagte ook op baie ander plekke in die Bybel (bv. Joh. 17:21, Efes. 4:4-6). Dit spreek dan vanself dat as die kerk 'n wesentlike eenheid vorm, dat die koinonia ook tussen die verskillende gemeentes gesien moet word. Nie net moet individuele gelowiges mekaar onderling help nie ( 1 Tim. $5: 4,8,16$ ) en nie net moet 'n gemeente individuele lidmate help nie, maar die een gemeente moet ook bereid wees om 'n ander gemeente te help.

Ons vind hiervan ook baie duidelike voorbeelde in die Skrif. So skryf die apostel Paulus bv. van 'n bydrae deur die gemeentes in Agaje en Macedonië vir die armes onder die gelowiges in Jerusalem (Rom. 15:26; vgl. 2 Kor. $8: 4,9 ; 9: 13$ ). Hierdie gemeentes het uit eie beweging aangedring om te mag deel (koinonia) in die liefdeswerk van hulpverlening (diakonia) aan die gelowiges (heiliges) in Judea (11 Kor. 8:4). En dan maak die Apostel hierdie sonderlinge uitspraak dat die wat oorvloed het die wat gebrek ly moet help sodat daar "ewewig" (gelykheid) kan wees (2 Kor. 8: 13-14). Ook t.o.v. die diakonia en die koinonia moet daar dus tussen die gemeentes gelykheid wees.

Hier kan spesifiek ook gedink word aan die groot bydrae wat die diakonië lewer t.o.v. ons kinder- en bejaarde-tehuise. 
In hierdie verband moet in besonder ook verwys word na hulp aan die jong kerke (die sogenaamde swart en bruin kerke). Dit word nog nie goed deur almal besef dat die Gerf. Kerk één kerkverband is met weliswaar eie gemeentes nie. Volgens die Skrif en gereformeerde kerkregtelike beginsels is daar egter nie sprake van 'n wit en swart en bruin kerk nie. Uit wat bo gestel is is dit dus logies dat die gedagte van koinonia ook oor die taalgrens heen vorm moet aanneem. Hieroor is nog nie veel geskryf nie hoewel 'n paar skrywers reeds die aandag hierop gevestig het." J. L. Helberg het by geleentheid spesifiek hieroor gehandel en dit is die moeite werd om aan sy prikkelende gedagtes aandag te gee. Ook J. A. Schutte het in sy Want ek het honger gehad en julle het my nie te ete gegee nie hierop die aandag gevestig. Volgens hom is 'n diakonale kerk 'n kerk wat hom waarlik solidêr voel met alle verdruktes en ellendiges afgesien van ras of kleur". ${ }^{8}$ 'n Belangrike saak wat hy na vore bring is die volgende: "Verder is dit seker die plig van die Here se kerk om ook deur sy diakonieë armoede te probeer voorkom, deur raadgewing, maar ook deur landswette en politieke beleide wat armoede ten gevolg het, te probeer verander deur o.a. die ongewenste toestande onder die aandag van die hoë owerheid te bring en deur gewetens aan te spreek waar nodig". Die diaken het hiervolgens ook 'n taak t.o.v. die owerheid waar dié 'n knellende sisteem sou handhaaf, asook teenoor werkgewers i.v.m. te lae lone.

Dit is myns insien uiters gewens dat daar oor en weer persoonlike diakonale kontak op gemeentelik vlak tussen die ou en jong kerke sal wees. Sodoende kan deeglike kennis opgedoen word t.o.v. sake soos werkloosheid, loonprobleme, behuisingsvraagstukke, honger, drankmisbruik ens. Sodoende kan broederlike advies gegee word in 'n gesindheid van koinonia en nie uit paternalisme nie. Sodoende kan d.m.v. die diakonaat uitdrukking gegee word aan die motief van eenheid en versoening in de kerk van die Here.

Dit is onnodig om die stoflike en geestelike nood in die jong kerke breed uit te spel. Dit is die taak van die ou kerke, met hulle groot rykdomme, om die barmhartigheid van Christus ook na buite uit te leef teenoor die jong kerke. Ons is immers saam die een kerk van Christus, die een volk van God; ons is saam diensbaar aan die Koninkryk van God. Alleen so bied ons ook 'n werklike alternatief op die aankomende Kommunisme met sy motiewe van kameraadskap en gelykheid. Ons het die antwoord hierop in die bestaan van die kerk, maar die kerk moet leer om weer uit sy verborge skatte en rykdomme te gaan leef. En dis die taak van die diakonieë om die oë van die gemeentes hiervoor te open.

Dink $u$ dis verantwoord van 'n diakonie - waarvan ek nou die dag gehoor het - om 'n reserwefonds van $\mathrm{R} 30000$ in die bank te hou? Gee die gelowiges geld vir barmhartigheidsdiens om in die bank belê te word - waar die mot en roes van inflasie dit in elk geval verniel - of word die geld gegee om bestee te word, om uitgedeel te word soos die Formulier sê?

Ek onderskei graag ook 'n derde aspek van diakonale sorg wat ons dan interkerklik kan noem.

Die volk van God bestaan trouens uit meer as net die Geref. Kerkverband. Ofskoon die sonde die kerk uitmekaar laat skeur het is daar tog nog heelwat ander kerkverbande met wie die Gerefor- 
meerde Kerk, hoewel ons met hulle nie noue bande van gemeenskap het nie op die terrein van barmhartigheidsdiens tog nou kan saamwerk en dit ter wille van die Koninkryk. Met die oog op die Koninkryk van God hoef die Christelike kerkgroepe nie teenstanders van mekaar te wees nie maar kan hulle medestanders wees, veral op die terrein van die menslike nood en ellende. Daaruit sal ook blyk dat die verskillende kerkgroepe, ondanks hulle verskille, tog vorme van eenheid openbaar.

Daarby is daar natuurlik ook projekte waar kerkverbande saamwerk, soos bv. by die Transoranje Instituut vir Buitengewone Onderwys. Dit sluit die volgende in: Transoranjeskool vir Dowes, Prinshofskool vir Swaksiendes, Sonitusskool vir Hardhorendes, Transvaliaskool vir Epileptici en Martie du Plessisskool vir Serebraalgestremdes.

Hier kan ook gedink word aan die ondersteuning van projekte soos die Jan Kriel Skool vir epiletici (Kuilsrivier) en die Skool vir Dowes en Blindes (Worcester). En wat van al die bruin en swart inrigtings in hierdie verband? Moet elke diakonie nie sorg om 'n behoorlike lys van inrigtings saam te stel sodat met diskresie hulp verleen kan word nie?

Ek kom by 'n laaste maar nogtans baie belangrike aspek nl. die buitekerklike hulp.

As dit vir ons eenmaal duidelik geword het dat die kerk en die diakonie nie net vir hulleself daar is nie maar ook vir die Koninkryk, dan is dit meteen duidelik dat die diakonale en kerklike hulp ook buite die grense van die gemeente en kerkverband moet gestalte aanneem. Gal 6:10 is in hierdie verband die oorbekende teks: "Solank ons die geleentheid het, moet ons dus aan ALMAL goed doen, veral aan ons medegelowiges." Die goeddoen begin dus by die kerk, by die medegelowiges, maar dit kring wyer uit, dit raak uiteindelik alle mense. In die bekende gelykenis van die Barmhartige Samaritaan (Luk. $10: 25-37$ ) word juis die skandalige optrede van die O.T. kerk (die priester en leviet) ontmasker!

Reeds in die Ou Testament word bepaal dat besondere sorg aan die vreemdeling, die nie-Israeliet, die nie-kerklidmaat, bestee moet word. Hy mag kos en klere en huisvesting nie ontbeer nie (Deut. $10: 18-19$, Jes. $58: 7$, Jer. $7: 6$ ).

Kyk ons na die optrede van Jesus Christus dan blyk duidelik dat Hy nie net 'n ope oog gehad het vir die nood van die siel van die mens nie maar ook vir die nood van die liggaam van die mens, nie net vir die nood binne Israel nie maar ook buite Israel. Hy het nie net gepreek nie maar ook geheel, ook buite die mure van Israel. En hoe kan die kerk van Christus 'n ander gesindheid daarop nahou? Hoe kan ons net na binnegerig lewe as ons ook 'n na buitegerigte opdrag het? Hoe kan ons net ons medebroeder en -suster help as die Here ook die heiden op ons pad plaas? Moet ons nie juis ook goed doen aan die wat ons haat nie? (Matt. 5:44). Moet ons nie juis ook kos gee aan ons vyande nie (Rom. $12: 20$ )?

Die kerk moet leer om nie net die "naby naaste" raak te sien nie maar ook die "verre naaste". Die kerk moet hoor van die nood op die wêreld wat soms hemelskreiende afmetings aanneem. Is dit dan nie hemeltergend as daar jaarliks meer as 30 miljoen mense op aarde 'n hongerdood sterf nie? Is dit menswaardig dat meer as die helfte van die mense op aarde onder die broodlyn leef? 
En waarom moet ons as Gereformeerde Christene aan die Wêreldraad van Kerke 'n vrye hand gee met sy wêrelddiakonaat? Waarom aan Worldvision? Waarom hoor ons so baie van die Rooi Kruis en Heilsleër se hulpprojekte? Waar is die Geref. Kerk? En waarom is dit so dikwels die SARK wat inspring in plakkersprobleemsituasies soms nogal op omstrede wyse? Waar is die diakens van die Geref. Kerk? Ons het wel Nasionale Sinodale Deputate vir Noodtoestande - en daar was 'n pragtige kerklike reaksie na die vloedramp vanjaar te Laingsburg - maar die werk van hierdie deputate moet aanmerklik uitgebou word.

Hulp in hierdie verband kan binnelands sowel as buitelands wees. Wat die binneland betref, kan gedink word aan hulp aan instansies soos die volgende: Die SA Blindewerkersorganisasie (Johannesburg), Die Connie Mulder Sentrum (vir verstandelik gestremdes bo 18 jaar) (Johannesburg), Pretoriase Vereniging vir die Versorging van Vertraagdes (Pretoria), SA Nasionale Raad vir Kinder- en Gesinsorg (Johannesburg), Die SA Noodhulpliga (Johannesburg), Die Nasionale Kankervereniging van SA, Sending aan die Melaatse (Johannesburg) ens.

Wat die buiteland betref kan ons dink aan hulp aan die Angolese vlugtelinge, aan die hongeriges van Oeganda, aan die nood agter die Ystergordyn ens.

Maar, soos gesê, ons Deputate Noodtoestande benodig grootskaalse uitbouing en vaartbelyning.

Miskien is een van ons probleme in hierdie verband juis die verhouding tussen woord en daad, tussen die hulpverlening "met uiterlike gawes" én "met gepaste trooswoorde uit die Woord van God". Tereg wys skrywers ${ }^{9}$ op die noue verband tussen die gee van die gawe en die bring van die evangelie en dat die twee nouliks vanmekaar losgemaak kan word. Christus het ons hierin ook 'n duidelike voorbeeld nagelaat. Dit is daarom altyd goed om op hierdie noue verband nadruk te lê. Tog is ek van oortuiging dat in ons komplekse wêreld daar 'n situasie ontstaan, waar dit vir die gewer van 'n gawe nie altyd moontlik sal wees om die evangelie van Christus saam met die uiterlike gawe te kan bring nie. Dit is bv. vir 'n kerk in SA prakties onmoontlik om iets te gee vir nood agter die Ystergordyn en dit dan te begelei met 'n evangeliewoord. In sulke gevalle spreek die voorbeeld van naasteliefde, al is dit ook sonder woorde, 'n duidelike taal (vgl. Matt: 5:16; 1 Pet. 3:2). Ook in die gelykenis van die Barmhartige Samaritaan gaan dit om die doodgewone daad van naasteliefde.

Ons moet hier duidelik wees en mekaar nie misverstaan nie. Die goeie reël is en bly dat die Christelike handreiking deur die evangelie van Christus begelei moet word. Dit is foutief om soos die WRK geld te skenk vir 'n PCR-fonds met die oog op humanitêre doeleindes terwyl daardie geld moontlik vir wapens gebruik kan word. Maar, daar kan omstandighede wees waar die kerk nie anders kan as om bloot te gee ter wille van noodlening nie.

Ek het taamlik uitgewy oor die diakonale taak. Ek het dit geplaas binne die raamwerk van die kerk en veral ook binne die raamwerk van die Koninkryk. Dit lyk dan of die diaken by sowat alles in die wêreld betrokke is en in 'n sekere sin is dit ook waar. Die diaken is die sement van die wêreld. Hy moet die gemeente opvoed 
tot 'n liefdesgemeenskap sodat hierdie liefde na binne tussen die broeders en susters en na buite op die strate van die wêreld gesien kan word. Op hierdie wyse word Jesus Christus as Koning gedien en op hierdie wyse word daar gewerk vir die Koninkryk van God en die nuwe wêreld waar almal waarlik vry is, waar net liefde heers en waar volle geregtigheid gevind word.

Aan hierdie groot gawe wat God skenk, moet ons as kerk en as diakens met die volle inset van ons bestaan diensbaar wees.

Voordrag tydens ' $n$ byeenkoms van diakens te Sasolburg op Sondag 18 Oktober 1981.

VOETNOTAS:

1. Vgl. ook J. H. Coetzee, Die barmhartigheidsdiens van die Gereformeerde Kerk in Suid-Afrika 1859-1949, Potchefstroom 1953; J. Postma ea, Die Diens van Barmhartigheid, Handleiding vir Diakens, Potchefstroom 1959.

2. Vgl. hier my verwysings in: Die Goue Kandelaar 1979, Potchefstroom. Voeg hierby nog L. Floor, Die plek van die diaken in die koninkryk van God in: Die Koninkryk van God, Potchefstroom 1969, 234-246 en die artikels van Christie Coetzee en Konkie van der Walt in: Venster op die Kerk, Potchefstroom 1980.

3. Floor a a 236.

4. $\mathrm{Vgl}$. my aangehaalde artikel bl. 21. Ander voorbeelde is ook te vind by Christie Coetzee a a 111-113 en Van der Walt aa.

5. Coetzee aa 107-108 en Floor a a 240.

6. Vgl. J. L. de Bruyn in: Die Prys van wat verkoop is aw 306, Coetzee aa 113 en Van der Walt aa 116-117.

7. J. L. Helberg, Diakonale sorg oor plaaslike volksgrense heen in: Die Prys van wat verkoop is aw 546-562.

8. J. A. Schutte, Want ek het honger gehad en julle het my nie te ete gegee nie, Potchefstroom sj, 29.

8a Vgl. J. Calvyn Institusie III $7: 6$.

9. Schutte a w 30 .

10. Floor aa 242, 244. Vgl. P. J. Pelser in: Die Prys aw 516-522. 